\title{
Identity-construction, mutual enskilment and political negotiation at the farmers' market
}

\author{
Maria Vasile \\ Leiden University - Leiden - The Netherlands \\ Fabiana Thomé da Cruz \\ Universidade Federal do Rio Grande do Sul - Porto Alegre - Rio Grande do Sul - \\ Brasil
}

\begin{abstract}
By focusing on the agroecological farmers' market of Menino Deus in Porto Alegre, Brazil, we explore how counter-hegemonic narratives and forms of knowledge are cultivated in such arenas. Informed by theories of practical knowledge as well as theoretical debates over ethics and politics of local food, we regard the farmers' market as a community of practice, where direct food procurement is a social relation entailing situated identity- construction, mutual enskilment, and political negotiation. The analysis is based mainly on ethnographic fieldwork conducted in Porto Alegre between March and June 2016, which included participant observation and semi-structured in depth interviews at the market of Menino Deus. The paper elaborates on the three above-mentioned dimensions (identityconstruction, mutual enskilment, and political negotiation) as central, parallel processes that take place at the market, making it an arena for debate over agri-food standards where local food, nutrition security and social justice are redefined and promoted. We highlight linkages between farmers' histories, visions, modes of production, and the governance mechanisms, enskilment processes and other activities at the market. In this way, we suggest that in this community technical aspects of procurement are re-embedded in the social domain and translate into new ways of life and visions of the future. This paper attempts to link reflections on the market place context, skill acquisition, and collective meaning negotiations, in order to contribute to the debate on local food as emancipatory project.
\end{abstract}

Keywords: Farmers' markets. Community of practice. Enskilment. Brazil. 


\section{Construção de identidade, capacitação mútua e negociação política em uma feira de agricultores}

\section{Resumo}

Neste artigo, ao analizar a Feira Ecológica do Menino Deus, em Porto Alegre, Brasil, exploramos como são construídas narrativas contra-hegemônicas e formas de conhecimento em espaços como o estudado. Partindo de teorias sobre conhecimento prático e de debates teóricos relacionados à ética e política da alimentação, consideramos a feira como uma comunidade de prática, em que a aquisição de alimentos diretamente de agricultores diz respeito a uma relação social que implica construção de identidades, capacitação mútua e negociação política. A análise está fundamentada principalmente no trabalho de campo etnográfico realizado em Porto Alegre entre março e junho de 2016, incluindo observação participante e entrevistas semiestruturadas em profundidada realizadas na Feira do Menino Deus. $O$ artigo explora as três dimensões acima mencionadas (construção de identidade, capacitação mútua e negociação política) como processos centrais e paralelos que ocorrem na feira, proporcionando arena frutífera para debates sobre padrões agroalimentares e sobre (re)defefinição e promoção da segurança alimentar e nutricional e justiça social. Destacamos vínculos entre experiências, visões e modos de produção dos agricultores e mecanismos de governança, processos de aprendizagem e outras atividades relacionadas a Feira. Nesse contexto, sugerimos que, na comunidade de prática estudada, aspectos técnicos dos processos de aquisição dos productos estão imersos no domínio social e se traduzem em novos estilos de vida e visões do futuro. Por fim, vale destacar que este artigo busca vincular reflexões sobre a feira, capacitação mútua e negociações coletivas a fim de contribuir para o debate sobre alimentos locais como um projeto emancipatório.

Palavras-Chave: Feiras de agricultores. Comunidade de prática. Capacitação. Brasil.

\section{Construcción de identidades, capacitación mutua y negociación política en una feria de agricultores}

\section{Resumen}

Al centrar el estudio en el mercado de agricultores agroecológicos de Menino Deus en Porto Alegre, Brasil, exploramos cómo se construyen las narrativas contra-hegemónicas y las formas de conocimiento en estos ámbitos. A partir de las teorías del conocimiento práctico y los debates teóricos sobre ética y política de la alimentación local, consideramos a este mercado de agricultores como una comunidad de práctica, donde la adquisición directa de alimentos es una relación social que conlleva la construcción de identidades, la transferencia de habilidades y la negociación política. El análisis se basa en el trabajo de campo etnográfico realizado en Porto Alegre entre marzo y junio de 2016, que incluyó observación participante y entrevistas semi-estructuradas en el mercado de Menino Deus. El artículo se centra en las tres dimensiones mencionadas anteriormente (construcción de identidades, transferencia de habilidades y negociación política) como procesos centrales y paralelos que tienen lugar en el mercado, lo que lo convierte en un escenario de debate sobre estándares agroalimentarios, así como (re)definición y promoción de la seguridad alimentaria y nutricional a nivel local, y la justicia social. Destacamos los vínculos entre las experiencias de los agricultores, sus visiones, los métodos de producción, mecanismos de gobernanza, los procesos de aprendizaje y otras actividades en dicho mercado. De este modo, sugerimos que en esta comunidad se reincorporen los aspectos técnicos en los procesos de adquisición al dominio social, y se traduzcan en nuevas formas de vida y visiones de futuro. Este trabajo vincula las reflexiones sobre el contexto, el mercado, las habilidades y las negociaciones 
colectivas de significados para contribuir al debate sobre la alimentación local como proyecto emancipador.

Palabras-Clave: Mercados de agricultores. Comunidad de práctica. Capacitación. Brasil.

\section{Introduction: getting to the market}

To get to the agroecological farmers' market of Menino Deus, you need to walk through the garden of the Rio Grande do Sul State Secretariat for Agriculture. You leave the barulho ('noise') of the Avenida Getúlio Vargas behind and, as you walk toward the large wooden marquee the sounds of the market become predominant. You can hear people chatting, oftentimes laughters, sometimes music, and you can feel that you are entering a calm and protecting space. Fourteen stands of family producers covered with fruits and vegetables, processed produce like jams and juices and, at times, cooked food, are on each side of the marquee. Regularly, the market also hosts guests such as local artisans, artists, cooks and resellers of organic products. Strolling along the stands, you can see the producers interacting with each other and with consumers, rearranging their products, passing around their chimarrão (regional typical beverage), and playing with children. The stands are colourful, the atmosphere is friendly and you come to realize that there is much more than food procurement taking place.

This market, named Feira da Cultura Ecológica do Menino Deus ('market of the ecological culture of Menino Deus') is the second oldest agroecological farmers' market ${ }^{1}$ of Porto Alegre, the capital of the Rio Grande do Sul, Brazil's southernmost state. It was established in 1993, as part of a broader movement of urban consumers requesting healthier and more sustainable food (Lemos, 2017, p. 13). From this movement, driven by principles of cooperativism and self-management, the cooperative Coolméia and what can be regarded as the first organic farmers' market in Brazil, known as FAE - Feira de Agricultores Ecológicos ('market of ecological producers') came into being, aiming at the development of organic production on the basis of dialogue with regional farmers (ibidem, 2017). Today, Porto Alegre counts 44 official agroecological farmers' markets situated in different neighbourhoods, each usually opened one or two days a week (PPA, n.d.). The municipality of Porto Alegre is involved in their regulation and recognizes their guiding criterion, which include the valorisation of quality local products, access to market for small-scale

\footnotetext{
${ }^{1}$ We define it as agroecological following local products terminology. These define agroecology as a science that valorises popular knowledge and progress new development pathways in a critical manner. The term organic is not usually employed in relation to the market but to products. Complementary to these empirical distinctions, it is important to present some of the theoretical approaches used to study these concepts. According to Abreu et al. (2012), organic and agroecological agricultures are part of distinct paradigms. While the basis of organic agriculture is soil science, the key principle of agroecology is ecology, followed by social and political dimensions. Organic agriculture is sometimes regarded as more limited because it represents an inputs substitution and not a broader movement. In this perspective, organic agriculture is related to agribusinesses, while agroecology is closer to the approach of family farmers, peasants, social movements, and public policies. Besides these distinctions, the authors emphasise that it is important not to polarize the debate between these two concepts because both can contribute to social, environmental and economic development.
} 
family farmers, promotion of solidarity and respect of the environment (Resolution 03/2012).

Similarly to other contexts, agroecological farmers' markets in Brazil represent sites where economic exchange combines with social and environmental action. As components of the country's complex agri-food system, these markets oftentimes display the materiality deriving from the luta ('struggle') for recognition of small-scale family farmers (Carmo, 2008). The organic rice from the assentamento Filhos de Sepé (one of the nearby farmers' settlement for the agrarian reform located in the municipality of Viamão), the vegetables certified through the participatory scheme of the Associação dos Produtores da Rede Agroecológica Metropolitana (Producers' Association of the Agroecological Metropolitan Network), the jams of the cooperativa AECIA de agricultores agroecologistas (a cooperative that gathers agroecological producers of the Serra Gaucha, a region in the state's hinterland) can be considered examples in this sense. The development of agroecological production and farmers' markets in this region needs indeed to be contextualized in the general agri-food panorama, which still presents challenges for farmers outside the conventional system - despite the historical improvements that resulted from Brazil's famous policies and grassroots movements in support of small-scale family farmers (Bruno, 2016). Even though discussing the economic, geographical and policy-related constraints faced by this category goes beyond the scope of this paper, it is important to recall that Brazil continues to present major inequalities and conflicts around issues of land ownership and control of natural resources (Oxfam, 2016; Penna \& Rosa, 2015), and that the contribution and production capacity of small-scale producers is still systematically called into question (e.g. Moreira, 2000, p. 48).

Getting to the feira of Menino Deus is therefore for many much more than walking through the garden of the state Secretariat. This space, before being a market, is a crossroad of stories of resistance of small-scale family farmers, revived and evolving through the market' practices. Stories of struggle for land, for fairer prices, for better rural living conditions and education, for autonomy and diversified production, make it a very particular social, cultural and political arena, where the dominant representations of production, consumption, knowledge and governance are contested in the praxis. While recognizing that farmers' markets can simultaneously include neoliberal traits and radical projects (e.g. Guthman, 2008; Leslie, 2017), this paper proposes to explore the counter-hegemonic narratives and forms of knowledge cultivated at the market. We do so by analysing market's activities as embedded in their social domain, linking them to questions of identities, skills, and collective negotiation.

This ethnographic account aims at contributing to debates over ethics and politics of local food (e.g. Hinrichs, 2003; Pratt, 2007; Tregear, 2011) by investigating interactions at farmers' market from the perspective of practice and practical knowledge theories (e.g. Ingold, 1993; Wenger, 1998; Grasseni, 2009). We approach the feira as a community of practice ${ }^{2}$, where particular visions, narratives and forms of knowledge are cultivated with regard to local food, nutrition security and social justice. This perspective helps us unravelling how the market constitutes, on one hand, a place for collective social and political action and, on the other, as more

\footnotetext{
${ }^{2}$ Communities of practice can be defined as "groups of people who share a concern or a passion for something they do and learn how to do it better as they interact regularly" (Wenger, 2011, p. 1).
} 
particularly analysed in this paper, how the processes of identity-construction, mutual enskilment and political negotiation are put into action. The information contained in this paper draws largely on participant observation (and conversations with producers and consumers) at the Menino Deus feira: six in depth interviews were conducted with its farmers and coordinator, as well as employees from extension services and Municipal Secretariat for Production, Industry and Commerce (SMIC) of Porto Alegre, who are working with local producers. Fieldwork was carried out between March and June 2016. During this period, the first author regularly visited and volunteered at the market, as well as visited some of its producers' farms. The analysis is also informed by the experience of the second author, who visits regularly the market and supervised a graduate thesis related to consumption at this market. The paper particularly emphasises farmers' perspectives, mainly due to the authors' research interests and desire to investigate their practices and experiences at the Menino Deus feira.

\section{We are the feira: on identity-construction at the market place}

Wenger (1998) argues that there is a strong connection between the development of practices, the formation of a community and the negotiation of identities. Identity, he advances, can indeed be explored as a negotiated experience: "We define who we are by the ways we experience ourselves through participation as well as by the ways we and others reify ourselves" (ibidem, 1998, p. 149). In this section, we explore how the market facilitates cultivation, (trans)formation and communication of farmers' identities, pointing out the importance of materiality, namely food, in such processes.

The relations among the producers who work at the Menino Deus feira are long-lasting and more than just work relations, as explained by the farmers' market coordinator: "Most of these farming families have been here since the first years of the market, some are the ones that actually built this structure". He has also been here since the beginning: he has known these farmers for almost 30 years, since most of them were acampados ('encamped rural landless workers'). "When I say that we know each other, I mean that we meet permanently, we live together. It is more than just a work relation. I have seen their children growing up and some of them are now graduating!". He also explained that these farmers were united by the choice of exiting what he named the pequeno cárcere ('small jail') where they were producing and selling products before transitioning to local agroecological production. Such transition had been for many a long journey: for the farmer R. this meant, abandoning the hinterland and grain production, forming a rural workers' association, occupying the Fazenda Annoni ${ }^{3}$, learning to produce vegetables, and converting to agroecological production.

\footnotetext{
3 In 1985, the occupation of the Fazenda Annoni (an estate of nine thousand hectares with no production situated in the municipality of Pontão, Rio Grande do Sul) was the first land occupation organized by families of the MST - Movimento dos Trabalhadores Rurais Sem Terra ('Landless Workers Movement') and involved around seven thousand rural workers (Moraes, 1987). In 1993, the area was allocated to the agrarian reform, which strengthened MST and the national diffusion of its practices which can be summarized in its motto"ocupar, resistir e produzir" ('occupy, resist and produce', Canofre \& Lopes, 2015).
} 
When conversing with the farmers at the market, it was possible to perceive that their life journeys were relatively different, but that they also had common traits, as emphasized in common discourses and symbolic means. This was particularly apparent in the case of farmers from the MST - Movimento dos Trabalhadores Rurais Sem Terra ('Landless Workers Movement') and other landless workers' movements, for which belonging to the movement represented a major trait of their identity. To be part of the movement meant sharing the experience of land occupation, related struggles, and political education. Rural social movements' general commitment to continuous formação ('education'), its schools and associational life had a key role in this perspective: fostering farmers' cohesion, women' leadership, broadening the movements' goal and advancing agroecology, to name a few ${ }^{4}$. At the market, this translated into particular (organizational) practices, counter-hegemonic discourses as well as in the use of specific language and symbols. In terms of narrative, MST farmers at the feira shared a similar discourse on the importance of women in agriculture and society, on the role of agroecology for people wellbeing and the environment, and on the destructive action of agribusinesses. In this context, farmers markets were commonly presented as central for the soustaiment of counteraction of small-scale producers: these constituted an opportunity for direct selling and thus for increasing small farms' economic viability, for distributing better quality (organic) products and for increasing farming' attractiveness. Concerning their organization, these farmers also carried with them at the market a tradition of regular collective discussion. This was exemplified by the fact that every market day some farmers had the custom to meet at least once, and to discuss jointly the various issues on the agenda. Differently than from the pequeno cárcere, where intermediaries would be taking the main decisions, in this environment producers had created the space to speak and decide for themselves. One day during fieldwork, after reporting on the main discussions the producers had had, one of them concluded: "When we discuss we come up with new ideas, and this is important because new projects should come from the producers themselves. It should be an idea of the producers, an idea of the people".

Not all producers at the market belonged to a social movement, and some actually came from quite different backgrounds. This was the case of a farmer who travelled to sell the products of his cooperative at the feira all the way from Antônio Prado5, a municipality in the hinterland of the state. He had transitioned to agroecology and started to sell at farmers' market in 1990, "after years of working with venenos ['poisons' - this term was used by many to describe agrochemicals]". This farmer is part of the cooperative AECIA - Associação dos Agricultores Ecologistas de Ipê e Antônio Prado ('association of ecological farmers of Ipê and Antônio Prado'), which is one of the first organic cooperatives in Brazil, created with the support of

\footnotetext{
${ }^{4}$ Readings on education, agroecology and counter-hegemonic discourses within the MST include the ethnographies of Turniawan (2015), Tarlau (2015) and Aguillar \& Cabreira (2016).

${ }^{5}$ The town, founded by Italian immigrants at the end of the 19th century, is famous for its Italians Brazilians population and their unique Talian (or Brazilian Venetian) dialect. As better understood during a visit to local farmers (as well as a tour in the town history museum), local inhabitants are very attached to their Italian background and the cultivation of Italian Brazilian traditions (architecture, music, artisanship, to name a few). As discussed with the farmers, the Italians that came to Brazil were very hard working people ("Taliani tuti bona gente") very attached to their family and land, which seemed to remain central values even today.
} 
the Centro Ecologico (local extension services' organization), today composed of 22 families. He explained: "We started discussing about the problems related to the use of chemicals [...]. The Centro Ecológico helped us to understand the reasons behind the green revolution: we understood that it was driven by the necessity to sell chemicals rather that to help farmers". As in the case of MST farmers, collective endeavours aiming at transforming a situation of oppression were at the heart of the journey of the members of AECIA. These farmers also shared analogous needs and faced common challenges, such as finding a way of marketing their organic products and dealing with insufficient on-farm labour force.

Some of these common visions become concrete at the market when observing the ways in which farmers dress (e.g. wearing MST movements' hats and t-shirts) or decorate their stands with cooperatives and farmers' association leaflets. In a similar way, their products, the way these are processed and/or presented, oftentimes also carry a reference to their background and work as identity symbols. The diversity of the produce - "You see here what you could never find in a supermarket"-, their freshness, the soil left on the vegetables, their local participatory certification labels are only few examples of the way in which farmers' discourses materialized at the market. Moreover, when asked about the products, farmers would discuss about their farming method and organization, and also about their identity as agroecological producers. As analysed in the literature linking skills and identity, skills can be regarded as "a privileged locus of identity-construction, as a complex of aesthetic involvement and moral stances, of strategies of belonging and expert practices" (Grasseni, 2009, p. 1). In the case of the farmers of the feira, their stories are tied to agroecology skilled practices: agroecology is not only a production method but also an attribute of their lifestyles, visions of the world and political stands. In other words, agroecology as a skill shapes farmers' identity as well as the landscape they engaged in: their stories portray how transitioning to a different agricultural system involves new relations with the soil, plants, animals, people and society, and entails a revived engagement in societal debates around food and nutrition security and local (food) movements (Méndez et al, 2012; Norder et al., 2016; Ikerd, 2018). Farmers' involvement in such broader debates was visible at the market when taking part in discussions about current events and public demonstrations. In 2016, it was common to engage in conversations about political events such as the landless women workers demonstration for recognition and better working conditions as agricultoras ('women farmers') at the INCRA (in March 2016), the encampment of farmers in support of Dilma Rousseff, the first woman to be Brazilian president, at Praça da Matriz, or more general public demonstrations organized in that period (characterized by the impeachment of the president). One day, while conversing, an MST farmer linked these demonstrations with his political education and culture explaining that MST farmers had partaken to a number of demonstrations in the past and had therefore developed particular skills, which made them well prepared to make 2016 protests long-lasting and as consequential as possible.

Overall, by selling their products collectively, farmers can cultivate common traits of their identities and communicate their efforts and hope for a more diversified, inclusive and healthy food system, transforming the market in a community of practice. As theorized by Wenger and exemplified above, communities of practices do not always presuppose strict "uniformity, conformity, cooperation, 
or agreement but entail a kind of diversity in which perspectives and identities are engaged with one another" (Wenger, 1998, p. 129). The materiality of the feira (i.e. the physical space, the products) is central to facilitate farmers' possibility to rework and communicate their identities. As explained in Wenger (1998) and Meyer (2009), materiality is key for collective meaning making, as we are "giving form to our experience by producing objects that congeal this experience into "thingness"' (Wenger, 1998, p. 58). In the case of the feira, embedding means that producers' arguments and practices are contextualized in their time and space, tangible in the products, which become instrumental to communicate an alternative approach to food production and distribution. Embedding also reinforces the identity of the market as a place (Gupta \& Ferguson, 2002).

\section{Farmers speaking for themselves: the market as a space for mutual enskilment and political negotiation}

Identity-construction is associated to a learning trajectory (Wenger, 1998). Contrarily to theories separating knowledge and practice, practice and practical knowledge theories explore learning as action (Palsson, 1994), as well as point out the social nature of learning and human action. In this body of literature, enskilment is defined as a way of learning by "immersion in the practical world" (ibidem, 1994, p. 901). This section explores the ways in which at the feira enskilment occurs as a collective and situated effort characterizing social relations. We report on different forms of "learning on the part of everyone" (Wenger, 2011, p. 4) observed in this community of practice and analyse such processes, specifically in terms of group binding and political negotiation.

"There was a time when people said that farmers did not need education, that farmers had to work in the field and that was all", delineated the farmers' market coordinator during an interview. Today things are different, he explained, as farmers have become aware of "the importance of knowledge sharing". In the coordinator's experience, this change was linked to the emergence of rural social movements and schools (for which he had worked for many years) as well as other pedagogical processes that involved farmers in learning and teaching. The feira appeared as one of these processes most visibly because representing a unique exchange opportunity between farmers and consumers. Many of the feirantes (people taking part in the feira) described the market as a space for encounter and discussion. For producers, it represented a chance for talking not only about the products but also about their identities and discourses "emplaced in skilled practice" (Grasseni, 2009, p. 2). For several consumers, on the other hand, the market was an almost unique urban space where to learn about food as well as transform into praxis their beliefs and political stands (e.g. to consume healthy food, to support marginalized categories, to contribute to the making of a local food system, to reconnect with the land and "what is really important"). Because of this (i.e. the feira being a singular site), consumers had a positive and open attitude demonstrated by the fact that many took the time to not only shop but also to dialogue and experiment.

It was possible to hear people conversing about the aesthetic of food, and farmers explaining what some products such as certain leafy vegetables or beans "really look like", re-educating in this way consumers' vision. "People in the city 
oftentimes do not know about the possible different shapes of uncleaned or unprocessed products", elucidated a farmer, pointing out that this was especially the case in relation to organic products, whose difference in size and colour (when compared to the ones in supermarkets) sometimes really struck consumers. Moreover, producers sometimes had to clarify why the price on their stand was reduced or why some of their products were different from the week before or the ones of other producers. In this way, consumers learned not only something about processes of food production and direct selling, but also about its related challenges. During such conversations, feirantes also exchanged about food preparation and recipes. Moreover, oficinas ('workshops') were organized at the market on a regular basis, representing a playful opportunity for consumers to learn how to make ice creams or special juices, to name a few. Visits at the farms of some of the market's producers were also proposed several times a year. More informally, some of the habitual consumers sometimes also assisted the farmers at their stand for some time. All of these forms of co-participation seemed to contribute to the development of "common criteria of action, perception and evaluation (both moral and aesthetic)" (Grasseni, 2009, p. 12), and to the maturing of a trust relation.

Some of the activities related to enskilment and knowledge sharing were particularly targeted to children. For example, a local carpenter was regularly invited at the market to organize sessions in which children would be constructing their own wooden games. Additionally, some of the producers present at the feira also partook in education projects in few schools in Porto Alegre. As described by the farmers' market coordinator (who supported the organization of the project): "We organise games in the schools in which children buy food by themselves. They buy salads, tomatoes [...]. You should see them talking about food, they are amazing!". He further explained: "We go in different schools and try to bring these concepts [agroecological production, food and nutrition security] to children, and after playing with us in the school the children usually bring their family to the market. When they arrive, they come to me and say hi! We created a strong link with them". The farmers at the feira seemed to regard food education for children as a mission, and more broadly the involvement of younger generation in these discussions as a steppingstone for the transformation of food habits and development of local sustainable food systems. These farmers recognized the importance of getting involved in critical food pedagogy, and in many cases this also seemed to correspond to an increased self-confidence. In fact, this entailed the possibility for a new role for farmers in society, creating an alternative imaginary to the one of marginality of small-scale farmers.

The processes described above make the farmers' market a space where different perspectives on alternatives ways of producing, eating, and different agropolitical visions come into contact. Rural perspectives meet with urban understandings of food system change, facilitating a process of integration between what might be regarded as a rural - urban cultural divide. For example, based on general observations, when discussing about these issues, many urban consumers initially tended to focus more on health-related issues and environmental matters, while producers focused more on social justice aspects. This intention was also illustrated in producers' terminological choice of defining and differentiating themselves as agroecological (and not organic) producers. By offering these new 
perspectives, farmers amplified consumers' vision over the problems linked to contemporary food systems, offering additional reasons and opportunities for political engagement.

The feira also appeared as a space for mutual enskilment among farmers. It reunited various "dynamics of knowledge in the valorisation of local food" (Fonte, 2008, p. 201): farmers shared skills related to agroecological and local knowledge, sometimes in contrast, sometimes aligned with the dominant paradigm of food production and food standards. These skills, even when relating to farmers' traditional knowledge, were never unchanging but rather in continuous transformation, influenced by exchanges with third parties (e.g. adapting to consumers' preferences) and changes in the socio-political context (e.g. regulations). For example, because of food safety standards, many farmers were forbidden to sell products processed at home for their own consumption ${ }^{6}$. Producers' associations (together with local extension services) had played an important role in supporting farmers to find ways to comply with regulations and adapt to new standards. In this context, adaptation was possible because of processes of mutual enskilment, allowing for collective solutions that represented a middle ground between standardization and valorisation of farmers' identity as small-scale family farmers to be discussed. Such enskilment also occurred at the feira through conversations and collective decision-making processes, during which farmers could express themselves and share their different experiences in their communities or associations. In this case, in line with what advanced in Grasseni (2007, 2009), skills emerged in alignment with a situation, because deeply linked to the context of the agents.

As exemplified in such processes, mutual enskilment of farmers at the feira occurred with regard to matters of organization, communication, negotiation, and more. These exchanges and mutual learning represented a stepping-stone for farmers' ability to formulate new requests and engage in broader political discussion. During fieldwork, it was possible to identify several ways in which enskilment at the market and political negotiation were connected. Generally, discussions at the market were an opportunity for farmers to get together, align their visions (beyond their community or association) and connect their efforts in a directed way, as in the case of food safety standards and challenges encountered in the production process, such as lack of processing facilities adapted to small-scale producers. By narrating how their group or association had dealt with such issues (and about their experience, more generally), farmers could empower others to think of possible solutions and new possibilities they could work towards. Moreover, it was possible to hear farmers debating about political events and working out their course of action, bringing with them insights from other debates and communities. In this process, they further developed their counter-hegemonic narratives together, by engaging in discussion and confronting their perspectives with more farmers and consumers. Moreover, as previously described, the feira served as a space where to cultivate a (collective) identity, and such process included political dimensions such

\footnotetext{
6 This type of artisanal products (e.g. jams, vegetables preserves), even though targeted as illegal, were demanded by some consumers, who appreciated these more than industrial ones.
} 
as growing consciousness of common conditions as small-scale family farmers ${ }^{7}$. All in all, these examples show how the feira represents for these farmers yet another community where to share, learn and discuss. At the same time, this community maintains its peculiar traits while including a very diverse range of actors (constumers included), and representing a site of encounter between rural and urban cultures, which seemed to correspond to a further enrichment of the political discussion and enskilment process on both sides.

\section{Conclusion}

This paper aimed at exploring an agroecological farmers' market not only as a commercial space but rather as a social and cultural environment, as well as a community of practice, where processes of identity-construction, mutual enskilment and political negotiation take place. As already discussed by several scholars, farmer's markets are spaces of sociability (e.g. Black, 2012) and such aspect can be particularly manifest in the case of agroecological markets, which, as we argue with the example of the Feira da Cultura Ecológica do Menino Deus, present specific dialogue opportunities among farmers as well as between farmers and consumers. Our analysis shed light on how the feira represents a chance for producers to sell their products, reinforce their relations with other producers and consumers, and, most importantly, cultivate their identities as small-scale family farmers. In fact, the products on the stands of the feira are at the basis of broader exchanges through which producers valorise and communicate their knowledge, their linkage to the land, and progress processes of mutual enskilment.

Enskilment is an integral part of identity-construction and facilitates group binding as well as putting into practice farmers' counter-hegemonic narratives and political negotiation. In these processes, farmers at the feira take on a new role of critical food pedagogues, becoming key actors for the advancement of local food and nutrition security, and social justice in the food system. As in the case of other farmers' markets across the globe, this occurs in a context in which neoliberal policies are hindering the development of socially just and sustainable food systems and limiting the potential of such markets (Leslie, 2017). Under these circumstances, the market increasingly becomes a precious societal space of resistance in practice, as exemplified by the processes of collective identity-construction and enskilment described in this paper. At the same time, dialogues at the market represent for consumers a way to reconnect with their food and with popular knowledge, by, for example, gaining insights on the seasonality of production or the influence of climate on the harvestings (Lemos, 2017). In our research, we recognize how for some consumers going to the market is also a way to translate into practice stands and beliefs in relation to food politics by supporting local small-scale agroecological producers $^{8}$. Exchanges at the market also seemed to facilitate the development of

\footnotetext{
7 See Bubinas (2011) for examples from a different context on how the market can facilitate the growth of "a class consciousness tied to economic behaviour", also for consumers.

${ }^{8}$ While writing this it is important to recall that in this research we did not investigate in depth the figures of the consumers. Existing literature, such as Lemos (2017), shows how the analysis of who these consumers are and what they are looking for can reveal a more complex picture, inviting for more critical reflections on politics of consumption at the market and question its potential to grow as a community.
} 
closer relations between producers and consumers, based on empathy, respect and admiration. Altogether, these parallel processes make the feira a space where alternative visions of the future are cultivated and, not without challenges, emancipatory projects meet and mature in the praxis. Further research is needed in order to investigate evolutions in this community of practice and other similar ones, and to explore the way processes of identity construction, enskillment and political negotiation evolve as new challenges are posed to Brasilian small-scale family farmers.

\section{Acknowledgments}

The authors would like to thank all the feirantes for sharing their time, insights and ideas. Their determination and creativity will forever remain sources of inspiration.

The first author worked on this paper as part of her PhD within the ERC Consolidator Project 'Food citizens? Collective food procurement in European cities: solidarity and diversity, skills and scale.' This project receives funding from the European Research Council (ERC) under the European Union's Horizon 2020 research and innovation programme (grant agreement No 724151).

\section{REFERENCES}

ABREU, Lucimar Santiago et al. Relações entre agricultura orgânica e agroecologia: desafios atuais em torno dos princípios da agroecologia. Desenvolvimento e Meio Ambiente, v. 26, 2012, p. 143-160.

BERNAVA, Aguillar; CABREIRA, Claudia Maria; ALDA, Maria. As práticas educativas em agroecologia do movimento dos trabalhadores rurais sem terra e os desafios frente as ordens impostas pelo capitalismo no campo brasileiro. Revista Tamoios, n.12, v. 2, 2016.

BRUNO, Regina. Desigualdade, agronegócio, agricultura familiar no Brasil. Estudos Sociedade e Agricultura, v. 24, n. 1, 2016, p. 142-160.

BUBINAS, Kathleen. Farmers markets in the post-industrial city. City \& Society, n. 23, v. 2, 2011, p. 154-172.

CANOFRE, Fernanda; Lopes, Gerson. Ocupar, resistir e produzir": Um novo modelo de vida nasce. 2015. Retrievable at: https://www.sul21.com.br/em-

destaque/2015/11/ocupar-resistir-e-produzir-um-novo-modelo-de-vida-nasce/

CARMO, Maristela Simões. Agroecologia: novos caminhos para a agricultura familiar. Revista Tecnologia \& Inovação Agropecuária. Dezembro 2018, p. 28-40.

FONTE, Maria. Knowledge, food and place: a way of producing, a way of knowing. Sociologia ruralis, v. 48, n.3, 2008, p. 200-222. 
GRASSENI, Cristina. Developing skill, developing vision: practices of locality at the foot of the Alps. New York, Oxford: Berghahn Books, 2009.

GRASSENI, Cristina. Introduction. In: Skilled visions: between apprenticeship and standards. Berghahn Books, 2007, pp. 1-19.

GUPTA, Akhil; FERGUSON James. Beyond "Culture": Space, Identity, and the Politics of Difference. In:. XAVIER, Jonathan Inda; ROSALDO, Renato (eds). The

Anthropology of Globalization. Malden: Blackwell Publishers, 2002, p. 65-80.

GUTHMAN, Julie. Neoliberalism and the making of food politics in

California. Geoforum, n. 39, v. 3, 2008, p. 1171-1183.

HINRICHS, C. Clare. The practice and politics of food system localization. Journal of rural studies, n. 19, v. 1, 2003, p. 33-45.

IKERD, John. Agroecology: Science, Farming System, or Social Movement?. 2018. Retrievable at: http://johnikerd.com/agroecology-science-farming-system-or-socialmovement/

INGOLD, Tim. Technology, language, intelligence: a reconsideration of basic concepts. In: GIBSON, Kathleen; INGOLD, Tim (eds). Tools, language and cognition in human evolution. Cambridge University Press, 1993, p. 449-472.

LAVE, Jean, WENGER, Etienne. Situated learning: Legitimate peripheral participation. Cambridge: Cambridge University Press, 1991.

LEMOS, Lilian Silva. Consumidores de produtos orgânicos/ecológicos da feira de agricultores do Menino Deus em Porto Alegre - RS. Trabalho de Conclusão de Curso (Bacharelado em Desenvolvimento Rural - PLAGEDER), Faculdade de Ciências Econômicas (FCE), Universidade Federal do Rio Grande do Sul (UFRGS), 2017.

LESLIE, Isaac Sohn. Improving farmers markets and challenging neoliberalism in Argentina. Agriculture and Human Values, n. 34, v. 3, 2017, p. 729-742.

MÉNDEZ , Ernesto V.; BACON, Christopher M.; COHEN, Roseann. Agroecology as a Transdisciplinary, Participatory, and Action-Oriented Approach. Agroecology and Sustainable Food Systems, v. 37, n. 1, 2013, p. 3-18.

MEYER, Birgit. From Imagined Communities to Aesthetic Formations: Religious Mediations, Sensational Forms, and Styles of Binding. In: MEYER, Birgit (ed.) Aesthetic Formations: media, religion and the senses. London: Palgrave Macmillan, 2009, p. 1-29.

MORAES, Tete. Terra para Rose. 1987. Retrievable at: https://vimeo.com/12323209 
MOREIRA, Roberto José. Críticas ambientalistas à revolução verde. Estudos sociedade e agricultura, v.8, n. 2, 2000, p. 39-52.

NORDER, Luiz Antônio. Agroecologia: polissemia, pluralismo e controvérsias ambiente \& sociedade. Ambiente \& Sociedade, v. XIX, n. 3, 2016, p. 1-20.

OXFAM. Terrenos da desigualdade: terra, agricultura e desigualdades no Brasil rural. Novembro, 2016. Retrievable at:

https://www.oxfam.org.br/sites/default/files/arquivos/relatorio-

terrenos_desigualdade-brasil.pdf.

PALSSON, Gisli. Enskilment at sea. Man: New Series, v. 29, n. 4, 1994, p. 901-927.

PENNA, Camila; ROSA, Marcelo C. Estado, movimentos e reforma agrária no Brasil: reflexões a partir do Incra. Lua Nova, n. 95, 2015, p. 57-87.

PPA. Prefeitura Municipal de Porto Alegre. Dispões sobre as feiras ecológicas. Retrievable at http://www2.portoalegre.rs.gov.br/smic/default.php?p_secao=206

PORTO ALEGRE. SMIC . Resolução no 3 de 26 de dezembro de 2012. Retrievable at: https://www.legisweb.com.br/legislacao/?id=249215

PRATT, Jeff. Food values: the local and the authentic. Critique of anthropology, n. 27, v. 3, 2007, p. 285-300.

TARLAU, Rebecca. How do new critical pedagogies develop? Educational innovation, social change, and landless workers in Brazil. Teachers College Record, n.117, v.11, 2015, p. 1-36.

TREGEAR, Angela. Progressing knowledge in alternative and local food networks: critical reflections and a research agenda. Journal of rural studies, n. 27, v. 4, 2011, p. 419-430.

TURNIAWAN, Marian Li. Constructing a Counter-Discourse: Agroecological Formação at the MST's Milton Santos School. Dissertation, Paper 286, Syracuse University, 2015.

WENGER, Etienne. Communities of practice: learning, meaning, and identity. Cambridge: Cambridge University Press, 1998.

WENGER, Etienne. Community of practice: a brief introduction. STEP Leadership Workshop, University of Oregon, 2011. Retrievable at:

https://scholarsbank.uoregon.edu/xmlui/handle/1794/11736 
Maria Vasile. Doutoranda no Instituto de Antropologia Cultural e Sociologia do Desenvolvimento na Universidade de Leiden. Pieter de la Court Building, Wassenaarseweg 52, 2333 AK Leiden, Holanda. m.vasile@fsw.leidenuniv.nl

Fabiana Thomé da Cruz. Professora colaboradora (Programa de Pós-Graduação em Desenvolvimento Rural) na Universidade Federal do Rio Grande do Sul. Av. João Pessoa, 31, Farroupilha, CEP: 90040000, Porto Alegre, RS, Brasil. fabiana.thome.da.cruz@gmail.com

\section{Submetido em: 08/11/2018}

\section{Aprovado em: 08/12/2018}

Como citar: VASILE, Maria; DA CRUZ, Fabiana Thomé. Construção de identidade, capacitação mútua e negociação política em uma feira de agricultores. Redes, Santa Cruz do Sul, v. 24, n. 1, p. 212226, jan. 2019. ISSN 1982-6745. Disponível em: https://doi.org/10.17058/redes.v24i1.13043. 